\title{
Shortage and inequalities in the distribution of specialists across community health centres in Uttar Pradesh, 2002-2012
}

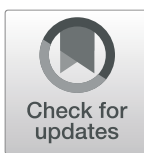

Aditya Singh(D

\begin{abstract}
Background: The onus of providing affordable access to specialist services in rural India primarily lies with publicly funded rural hospitals, also known as community health centres (CHCs). However, no studies have attempted to measure the change in the shortage and distributional inequalities of specialists in the publicly funded rural hospitals of Uttar Pradesh (India). This study attempts to fill that gap.
\end{abstract}

Methods: The study uses data from the three latest rounds of the District-Level Household Survey, covering a period of 10 years spanning from 2002 to 2012. Shortages were measured against the Indian Public Health Standards for $\mathrm{CHCs}$, and inequalities were measured using Gini and Theil indices, with the latter decomposed to reveal the source of the inequalities. Negative binomial regression was applied to examine the association between facility characteristics and the availability of specialists in CHCs.

Results: The current shortage of specialists stands at $80.7 \%$ of the total requirement. Currently, $62.1 \%$ of CHCs are functioning without a specialist. The distribution of specialists across $\mathrm{CHCs}$ has become progressively uneven over the study period, as shown by the rise in the Gini index (from 0.41 in 2002-2004 to 0.74 in 2012-2013). Decomposition analysis reveals that the contribution of within-district inequalities to overall inequality remains high ( $85.4 \%$ of total inequality). About $50 \%$ of within-district inequality is contributed by only 20 districts, most of which belong to eastern and central Uttar Pradesh. The analysis of factors affecting the distribution of the current specialist workforce revealed that the number of available specialists at a CHC is positively associated with the availability of residences for doctors and regular electricity supply, and negatively associated with $\mathrm{CHC}$ location and the distance of the CHC from the district headquarters.

Conclusion: The findings suggest that Uttar Pradesh not only needs to recruit more specialists, but it also requires proper implementation of deployment and retention policies to ensure equitable access to specialist care for rural populations. Ensuring the availability of quality accommodations and basic amenities at all CHCs, as well as adequate transport and rural allowance, could help increase the chances of specialists staying in rural and far-off CHCs.

Keywords: Human resources for health, Specialists, Community health centres, India, Uttar Pradesh, Health worker shortage

Correspondence: aadigeog@gmail.com

Independent researcher, Sitapur, Uttar Pradesh, India

(c) The Author(s). 2019 Open Access This article is distributed under the terms of the Creative Commons Attribution 4.0 International License (http://creativecommons.org/licenses/by/4.0/), which permits unrestricted use, distribution, and reproduction in any medium, provided you give appropriate credit to the original author(s) and the source, provide a link to the Creative Commons license, and indicate if changes were made. The Creative Commons Public Domain Dedication waiver (http://creativecommons.org/publicdomain/zero/1.0/) applies to the data made available in this article, unless otherwise stated. 


\section{Background}

Government health services in rural India are mainly provided through a three-tier hierarchy of publicly funded health facilities, with community health centres (CHCs) - 30-bed, $24 \times 7$ rural hospitals that serve about 120,000 people - at the top, primary health centres (PHCs) in the middle, and health sub-centres (HSCs) at the bottom [1]. While HSCs and PHCs provide essential healthcare services, the $\mathrm{CHC}$ provides specialist services and acts as a referral centre for the PHCs and HSCs in its catchment area. It provides specialist services to deal with surgical, paediatric, obstetric, and gynaecological emergencies through a team of healthcare professionals that includes four specialist doctors (doctors with a postgraduate medical degree in specific areas), namely surgeon, paediatrician, obstetrician, and anaesthetist [2].

Since private health facilities that offer specialists services are mostly found in urban areas, the onus of providing access to specialist services in rural areas primarily lies with $\mathrm{CHCs}$ [3]. The shortage and unequal distribution of a specialist workforce at the $\mathrm{CHC}$ level can have serious implications not only for maternal and child mortality, but also for the quality of health-service delivery at higher levels, such as in district or regional hospitals [4]. Since the rural poor mostly rely on publicly funded facilities for their healthcare needs, the lack of specialists at the $\mathrm{CHCs}$ often forces them to either forgo treatment or avail specialist services from the private sector, which is infamous for its exorbitant fees $[5,6]$. The lack of $\mathrm{CHC}$ specialists may cause higher disease burden and mortality for the rural population, and it could also trap rural households into a vicious poverty cycle due to the high out-of-pocket expenditures faced when seeking medical care [5].

The lack of specialists in CHCs also forces the rural poor to seek specialist services from higher-level, publicly-funded hospitals (such as district hospitals and medical colleges) or other CHCs in proximity [7]. The influx of those patients who should have been treated at their local $\mathrm{CHC}$, into the higher-level facilities that are meant for complex and serious cases or in other $\mathrm{CHCs}$, often results in overcrowding, long queues, delays in treatment, and untimely deaths [8]. The lack or unequal distribution of the health workforce (for instance, specialists across $\mathrm{CHCs}$ ) could also lead to the ineffective use of physical infrastructure and equipment, rendering the invested infrastructure and equipment useless [9]. Hence, it is important to ensure that all $\mathrm{CHCs}$ are equipped and staffed with a team of four specialists, as recommended by the Indian Public Health Standards (IPHS) of the Government of India.

The state of Uttar Pradesh (UP), home to over 200 million people, is the largest state in India in terms of population size [10]. It is usually ranked lower than the other states in terms of health- and mortality-related indicators, especially in maternal and child mortality. For instance, the current maternal mortality ratio (MMR) (300 maternal deaths per 100,000 births) and infant mortality rate (IMR) (50 deaths per 1000 births) is about same as the MMR and IMR of many underdeveloped and poor African countries [11]. To improve the situation and reduce the level of burden placed on higher-level facilities, the state of UP not only needs a strong pool of doctors, nurses, and midwives for PHCs and HSCs but also requires a strong and effective specialist workforce at the rural CHCs.

Although the state has rapidly expanded its network of rural health facilities in the last decade, and the number of CHCs in the state has more than tripled [12], little is known about the changes that have occurred in the size and distribution of the health workforce at $\mathrm{CHC}$ level in UP. The focus of previous studies on the health workforce in India has been primarily on doctors, nurses, and midwives, and specialist doctors have never received due attention [13-17]. Much of the past literature that measured distributional inequalities and shortages in specialists have emerged from developed countries [18-20].

The aim of this study, therefore, is to measure the change in the shortage and inequality in the distribution of a specialist workforce across publicly funded rural hospitals in UP, while accounting for the sources of those inequalities during a period of about 10 years (between 2002 and 2004 and 2012-2013), which is when major health system reforms were implemented and the number of $\mathrm{CHCs}$ had increased significantly within the state [21]. This paper also aims to identify the factors associated with variation in the availability of specialists across $\mathrm{CHCs}$ during the most recent period for which data are available (i.e., 2012-2013).

\section{Methods}

\section{Data source}

The data for this study are from the three latest rounds (2002-04, 2007-08, and 2012-13) of a series of nationally representative surveys known as the District-Level Household and Facility Survey (DLHS). All Facility Surveys included in this study collected information on the available resources (health personnel, physical infrastructure, medical equipment, and drug availability) at all $\mathrm{CHCs}$ in the state of UP. This study uses information on 257 CHCs from DLHS-2, 693 CHCs from DLHS-3, and $920 \mathrm{CHCs}$ from DLHS-4. The number of CHCs in the state has increased over the years due to expansion of health facilities in rural areas. The details of the sampling strategy adopted for the survey, questionnaires, response rate, and so on can be found in national reports that are publicly available at http://rchiips.org/. This study is based on anonymous public use dataset with no 
identifiable information on the survey participants. The data can be requested from http://www.iipsindia.ac.in/.

\section{Statistical analysis}

The shortage of specialists is estimated against the norms set by the Indian Public Health Standards (IPHS). The IPHS requires each $\mathrm{CHC}$ to be equipped with four specialists - namely, surgeon, paediatrician, obstetrician, and anaesthetist. Thus, the minimum and maximum number of specialists in a $\mathrm{CHC}$ should ideally vary between zero and four, respectively.

The summary measures of inequality used in this study are the Gini coefficient (with Lorenz curve) and Theil's ' $T$ '. The Gini index is a well-known and widely used measure of inequality that measures aggregate-level inequality [13]. The Gini coefficient varies between 0 and 1 , with higher values indicating higher levels of inequality. Since its upper and lower bounds are fixed, the magnitude of inequality that it measures can be easily understood and compared (Anand, 2010). The Gini (G) can be expressed as:

$$
G=\frac{2 \operatorname{covar}\left(y, r_{y}\right)}{N \bar{y}}
$$

Where covar $\left(y, r_{y}\right)$ is the covariance between the numbers of specialists at $\mathrm{CHCs}(y)$ and rank of the $\mathrm{CHCs}$ according to the number of specialists available $\left(r_{y}\right)$ ranging from poorest $\mathrm{CHC}(\mathrm{rank}=1)$ to the richest $($ rank $=N) . N$ is the total number of $\mathrm{CHCs}$ and $\bar{y}=$ average number of specialists per $\mathrm{CHC}$.

The Gini index is non-decomposable (i.e., the Gini index is not equal to the sum of the Gini coefficients of its subgroups) [22]. Conversely, Theil's $\mathrm{T}$ is additively decomposable, which means that it can account for different sources of inequality [23]. This index has been widely used in the past since it is a perfectly decomposable measure of inequality [13, 15, 24-27]. The values of Theil's $T$ vary between 0 and $\infty$, with 0 representing an equal distribution and higher values representing a higher level of inequality [28]. Theil $\mathrm{T}$ can be decomposed into 'between' and 'within' inequalities. Decomposition involves a partition of units $(\mathrm{CHCs})$ into mutually exclusive and exhaustive groups (such as districts in the state), as well as a calculation of two separate components of overall inequality: a weighted sum of inter-CHC inequality within each district, called the "within-group" inequality, and a "between-group" component that measures inequality that is solely due to variations in specialists' density across districts [13].

If there are $m$ districts in a state, the decomposable Theil index can be expressed as -
Theil $\boldsymbol{T}$ or $\boldsymbol{G E}(1)=\sum_{i=0}^{m} s_{i} T_{i} \sum_{i=0}^{m} s_{i} \ln \left(\frac{\bar{y}_{i}}{\bar{y}}\right)$

Where, $s_{i}$ is specialist share of the district $i$ (total number of specialists in the district/total number of specialists in the state), $\bar{y}_{i}$ is the average number of specialists per $\mathrm{CHC}$ in the district $i, \bar{y}$ is the average number of specialists per $\mathrm{CHC}$ in the state.

$T_{i}$ in the Eq. 1 is the Theil index for the district $i$ and can be written as -

$$
T_{i}=\frac{1}{N} \sum_{i=1}^{N} \frac{y_{i}}{\bar{y}_{i}} \ln \left(\frac{y_{i}}{\bar{y}_{i}}\right)
$$

Where, $\mathrm{N}$ is the total number of $\mathrm{CHCs}$ in the district $i, y_{i}$ is the total number of specialist available at a $\mathrm{CHC}$ in the district $i, \bar{y}_{i}$ is the average number of specialists per $\mathrm{CHC}$ in the district $i$.

The first part of the Eq. 1 represents "within-group" or "within-district" inequality. The second part represents "between-group" or "between-district" inequality. The 'between' inequality values for districts could be either negative or positive, depending on their average number of specialists per $\mathrm{CHC}$ compared to average number of the specialists per $\mathrm{CHC}$ in the state. A negative value for a district indicates a lower number of specialists available per $\mathrm{CHC}$ in that district when compared to the number of specialists available at a typical health facility in the state. The 'within' inequality values are always positive. The combined value provides the net contribution of each district to overall inequality. Again, the net (within and between) contribution of each district could be negative or positive, and the total values comprise the overall Theil's $\mathrm{T}$, which is always positive [15]. For a detailed example of the calculations that have been made in this study to arrive at Theil index, please refer to Appendix. The unit of analysis is CHC. Stata command ineqdeco has been used for calculating decomposable Theil $\mathrm{T}$ and Gini [29].

Negative binomial regression has been used to examine the association between specialist availability at a given $\mathrm{CHC}$ and the facility's characteristics. The dependent variable, 'the total number of specialists at a $\mathrm{CHC}$, is a count variable with a mean of 0.74 and a variance of 1.47. Since the dependent variable consists of non-negative count data, the negative binomial regression technique was chosen for the analysis [30]. The possibility of using a Poisson regression model is ruled out given its strict assumption that the mean and variance of the dependent variable should be same [31]. As mentioned above, the mean of the dependent variable in this study is not equal to its variance; it exhibits a clear over-dispersion. In such cases, a Poisson regression model usually produces inefficient estimates. Conversely, 
a negative binomial model does not require assumptions of mean and variance equality; it also allows for unmeasured characteristics that generate over-dispersion in the count data [32]. Hence, a negative binomial model was preferred over a Poisson model for this study.

The negative binomial regression model used in this study can be written as follows:

$$
Y_{f d}=\beta_{0}+\beta_{1} X_{1}+\beta_{2} X_{2}+\beta_{3} X_{3}+\ldots+\beta_{n} X_{n}
$$

Where $Y$ is the outcome variable (the total number of specialists at the $\mathrm{CHC} f$ in district $d$ ) and $\mathrm{X}_{1}, \mathrm{X}_{2}, \mathrm{X}_{3 \ldots} . \mathrm{X}_{n}$ represent facility characteristics that could affect the outcome. The results are presented in the form Incidence Rate Ratios (IRRs). The model was tested to determine potential multicollinearity among the independent variables using variance inflation factor (VIF) as a post-estimation procedure. The overall VIF for the final model is very small (1.79), indicating that there exists no significant multicollinearity among the independent variables.

Over dispersion is estimated using a parameter called alpha. If alpha is zero, then the data are not over-dispersed and a Poisson model is suitable. If alpha is greater than zero, then the data are over-dispersed and the negative binomial distribution models the data more accurately than the Poisson distribution. To test that the dispersion parameter alpha is equal to zero, a likelihood ratio chi-square test was applied, the results of which are also presented along with the model. The large test statistics with very small $P$-values suggest that the response variable is over-dispersed and is better estimated using a negative binomial model than a Poisson model.

The analysis was conducted using Stata (version 12.0) statistical software [33] and the command used for regression analysis was $n b r e g$.

Health worker availability in a health facility could be influenced by a host of complex and interconnected factors, linked to health workers' characteristics and preferences and related to health systems organization and wider social, political and economic environment. Most commonly reported factors include: inappropriate pre-service training for rural and remote areas practice, lack of prospects for further training and career development, low salaries, poor working environments, limited availability of equipment and drugs, insufficient family support, inadequate management and unsupportive supervision. Although the choice of variables included in this study is guided by the existing literature [34-41], the study could include only a limited number of variables that are available in the DLHS-4 dataset. A detailed description of the variables included in the analysis is given in the table below (Table 1).
Table 1 Operational definition and categorization of variables

\begin{tabular}{|c|c|}
\hline Variables & Description \\
\hline \multicolumn{2}{|l|}{ Dependent variable } \\
\hline $\begin{array}{l}\text { Availability of } \\
\text { specialists }\end{array}$ & $\begin{array}{l}\text { The total number of specialists available at a } \mathrm{CHC} \text { - } \\
\text { varies from } 0 \text { to } 7\end{array}$ \\
\hline \multicolumn{2}{|c|}{ Independent variables } \\
\hline $\begin{array}{l}\text { Number of } \\
\text { workers }\end{array}$ & $\begin{array}{l}\text { Total number of health worker available at CHC } \\
\text { (except specialists) }-<=10 ; 11-20 ; 21-30 ; 30+\end{array}$ \\
\hline Residence & $\begin{array}{l}\text { Total number of residences available for specialists } \\
\text { - None; One; Two; Three; Four }\end{array}$ \\
\hline Water & $\begin{array}{l}\text { The main source of water at CHC - Tap (piped } \\
\text { water supply); Others (bore well, tube well or } \\
\text { traditional well); None }\end{array}$ \\
\hline Electricity & $\begin{array}{l}\text { Whether the } \mathrm{CHC} \text { has a three-phase electricity } \\
\text { connection - Yes; No }\end{array}$ \\
\hline FRU & $\begin{array}{l}\text { Whether the CHC is designated as First Referral } \\
\text { Unit - Yes, No }\end{array}$ \\
\hline Location & Where is the CHC located? Rural area; Urban area. \\
\hline Distance to $\mathrm{DH}$ & $\begin{array}{l}\text { The distance of CHC from the district headquarters } \\
(\mathrm{DH})-<=5 \mathrm{kms} ; 6-10 \mathrm{kms} ; 11-30 \mathrm{kms}, 31-50 \mathrm{kms} ; \\
50+\mathrm{kms} \text {. }\end{array}$ \\
\hline
\end{tabular}

\section{Results}

\section{Shortage of specialists at CHCs}

Table 2 provides the details of the overall shortage of specialists at the CHCs over a decade spanning 20022004 and 2012-2013. The total number of specialists required for $\mathrm{CHCs}$ in UP during 2002-2004 was 1024 - almost two and half times higher than the available number of specialists $(n=471)$ at that time. Although the availability of specialists at the CHCs increased by about $50 \%$ during the study period, the overall shortage of specialists, which was about $54 \%$ of the total requirement in 2002-2004, had shot up to $81 \%$ in 2012-2013; overall, the shortage of all the different specialists grew to reach above $80 \%$. The biggest shortage was recorded for anaesthetists, which held true for all three time points included in this study. However, the shortage of surgeons witnessed the greatest surge, as it grew from 36\% in 2002-2004 to $84 \%$ in 2012-2013. A similar surge was recorded in the case of paediatricians as well; however, the shortage of obstetricians and anaesthetists, which was already considerably high in 2002-2004, rose by only about 10-12 percentage points over these 10 years.

The population-based IPHS norm requires at least one $\mathrm{CHC}$ to be established for every 120,000 people. To fulfil this norm, the state should have $1292 \mathrm{CHCs}$ to serve its 160 million people who live in rural areas. After considering the IPHS norm, the current shortage increases by about another $5 \%$ to reach $86 \%$. Similarly, the shortage of surgeons and anaesthetists approached 90\% of their total requirement. 
Table 2 Requirement, availability and shortage of specialists at community health centres in Uttar Pradesh, India, 2002-13

\begin{tabular}{|c|c|c|c|c|c|c|}
\hline Period & & Surgeon & Paediatrician & Obstetrician & Anaesthetist & Total \\
\hline \multirow[t]{4}{*}{$2002-04$} & Available & 163 & 144 & 101 & 63 & 471 \\
\hline & Required & 256 & 256 & 256 & 256 & 1024 \\
\hline & Shortage & 93 & 112 & 155 & 193 & 553 \\
\hline & Shortage (\%) & 36.3 & 43.8 & 60.5 & 75.4 & 54.0 \\
\hline \multirow[t]{4}{*}{ 2007-08 } & Available & 202 & 147 & 228 & 127 & 704 \\
\hline & Required & 693 & 693 & 693 & 693 & 2772 \\
\hline & Shortage & 491 & 546 & 465 & 566 & 2068 \\
\hline & Shortage (\%) & 70.9 & 78.8 & 67.1 & 81.7 & 74.6 \\
\hline \multirow[t]{4}{*}{ 2012-13 } & Available & 146 & 180 & 251 & 132 & 709 \\
\hline & Required & 920 & 920 & 920 & 920 & 3680 \\
\hline & Shortage & 774 & 740 & 669 & 788 & 2971 \\
\hline & Shortage (\%) & 84.1 & 80.4 & 72.7 & 85.7 & 80.7 \\
\hline \multirow[t]{3}{*}{ IPHS (2012-13)* } & Required & 1292 & 1292 & 1292 & 1292 & 5168 \\
\hline & Shortage & 1146 & 1112 & 1041 & 1160 & 4459 \\
\hline & Shortage (\%) & 88.7 & 86.1 & 80.6 & 89.8 & 86.3 \\
\hline
\end{tabular}

Note: IPHS Indian Public Health Standards (2012); * Population based IPHS norms (2012) require one CHC per 120,000 people; Shortage = Required - Available;

Shortage $(\%)=($ Shortage/Required $) * 100$

\section{Distribution of specialists}

The average number of specialists in the CHCs of UP during 2002-2004 was 1.84. This decreased considerably over the following 10 years to 0.79 specialists per $\mathrm{CHC}$. Table 3 shows the distribution of specialists across $\mathrm{CHCs}$ in UP. About $20 \%$ of all CHCs did not have even a single specialist, while another $23 \%$ of CHCs had only one specialist in 2002-2004. The situation worsened since then, as in 2012-2013, the proportion of CHCs without any specialists increased to $62 \%$ in 2012-2013, while the proportion of $\mathrm{CHCs}$ with one specialist decreased slightly by four percentage points. The proportion of $\mathrm{CHCs}$ with two, three, four, and five or more specialists also reduced substantially during this time.

Among the different categories of specialists, the proportion of $\mathrm{CHCs}$ without a specialist have increased substantially during the study period. For instance, the proportion of $\mathrm{CHCs}$ without a paediatrician rose from $48 \%$ in $2002-2004$ to $81 \%$ in $2012-2013$. The case was similar for the other three specialist types, although the increase in the proportion of such CHCs was not as high as in the case of paediatricians. In 2012-2013, about $14 \%$ of $\mathrm{CHCs}$ had one or more surgeon, while $20 \%$ had one or more obstetrician in position. Paediatricians and anaesthetists were available in 19 and $17 \%$ of $\mathrm{CHCs}$, respectively.

Table 4 presents an overview of the placement of available specialist doctors across CHCs during the study period. It was found that of all $\mathrm{CHCs}$ that had an available specialist in 2012-2013, 55\% of these health centres had only one specialist. The proportion of $\mathrm{CHCs}$ that had all four specialists was only about 6\%. The proportion of $\mathrm{CHCs}$ that had two to three specialists (but no anaesthetist) was about $22 \%$. Thus, one can see that there was - and still is -considerable variation in the distribution of specialists across CHCs. The next section will, therefore, provide details on the distributional inequality of specialists, as measured by widely

Table 3 Distribution of community health centres by number of specialists in Uttar Pradesh (India) during 2002-13

\begin{tabular}{|c|c|c|c|c|c|c|c|}
\hline \multirow[t]{2}{*}{ Year } & \multirow{2}{*}{$\begin{array}{l}\text { Type of } \\
\text { specialist }\end{array}$} & \multicolumn{6}{|c|}{ Number of specialists } \\
\hline & & 0 & 1 & 2 & 3 & 4 & $5+$ \\
\hline \multirow[t]{5}{*}{$2002-04(n=256)$} & Surgeon & 37.9 & 59.8 & 2.0 & 0.3 & 0.0 & 0.0 \\
\hline & Obstetrician & 63.7 & 34.4 & 1.5 & 0.4 & 0.0 & 0.0 \\
\hline & Paediatrician & 48.4 & 47.3 & 3.9 & 0.0 & 0.4 & 0.0 \\
\hline & Anaesthetist & 75.4 & 24.6 & 0.0 & 0.0 & 0.0 & 0.0 \\
\hline & All specialists & 20.3 & 23.1 & 23.8 & 21.9 & 7.4 & 3.5 \\
\hline \multirow[t]{5}{*}{$2007-08(n=693)$} & Surgeon & 72.7 & 26.0 & 1.0 & 0.1 & 0.0 & 0.1 \\
\hline & Obstetrician & 70.1 & 27.1 & 2.5 & 0.3 & 0.0 & 0.0 \\
\hline & Paediatrician & 78.2 & 20.9 & 0.9 & 0.0 & 0.0 & 0.0 \\
\hline & Anaesthetist & 82.7 & 15.9 & 1.0 & 0.4 & 0.0 & 0.0 \\
\hline & All specialists & 48.3 & 20.4 & 16.6 & 10.0 & 4.2 & 0.6 \\
\hline \multirow[t]{5}{*}{$2012-13(n=920)$} & Surgeon & 85.5 & 13.6 & 0.4 & 0.3 & 0.1 & 0.0 \\
\hline & Obstetrician & 80.0 & 16.7 & 2.5 & 0.8 & 0.0 & 0.0 \\
\hline & Paediatrician & 81.4 & 17.7 & 0.8 & 0.1 & 0.0 & 0.0 \\
\hline & Anaesthetist & 88.5 & 10.1 & 0.8 & 0.3 & 0.1 & 0.2 \\
\hline & All specialists & 62.1 & 19.1 & 8.2 & 7.0 & 2.3 & 1.4 \\
\hline
\end{tabular}

Note: All figures are in percent. Interpretation - 37.9 should be interpreted as follows $-39.7 \%$ CHCs are functioning without any surgeon. 59.8 should interpreted as follows $-59.8 \%$ CHCs have one surgeon. ' $n$ ' is the number CHCs 
Table 4 Placement of specialist doctors across community health centres in Uttar Pradesh during 2002-04, 2007-08, and 2012-13

\begin{tabular}{llll}
\hline Availability of health workers & $2002-04(n=204)$ & $2007-08(n=358)$ & $2012-13(n=-349)$ \\
\hline Only Anaesthetist & 3.4 & 8.1 & 7.4 \\
Only Paediatrician & 9.8 & 8.7 & 18.1 \\
Only Surgeon & 12.7 & 14.0 & 11.5 \\
Only Obstetrician & 3.4 & 12.0 & 18.3 \\
Two or more specialists with anaesthetist/s & 18.6 & 19.6 & 17.2 \\
Two or more specialists with no anaesthetist & 43.1 & 31.8 & 21.8 \\
All four specialists available & 8.8 & 5.9 & 5.7 \\
\hline
\end{tabular}

used measures of inequality - Theil's ' $\mathrm{T}$ ' and the Gini coefficient.

\section{Overall inequality}

Table 5 provides a glimpse of the overall inter-CHC inequality in the distribution of specialists and other categories of health workers (doctors, nurses, and allied health professionals) at $\mathrm{CHCs}$ for the study period (i.e., 2002-2013). Overall health worker inequality decreased by about $31 \%$ (11 Gini points) during the period. This decrease is visible in Theil's $\mathrm{T}$ as well, which dropped from 0.025 in 2002-2004 to 0.12 in 2012-2013. The same is true for all other health worker categories as well, except for specialists. The inequality in the distribution of specialists rose by about 78\% (33 Gini points). Regarding Theil's T, the unequal distribution of specialists had gone up from a modest 0.34 , reaching a high of 1.14 . It is interesting to note that the 2002-2004 inequality for doctors and nurses is much lower than that for specialists, but the reverse is true for the latest time point (i.e., 20122013). The inequality for specialists in 2012-2013 is considerably higher than the inequality for nurses and doctors.

The Gini coefficient for all categories of specialists is above 0.80 , which suggests that their distribution is highly unequal. Anaesthetists are the most unequally distributed among all (Theil's ' $T$ ' $=2.30$; Gini $=0.91$ ). The same is true for their 2002-2004 distribution as well. The biggest change in distributional inequality occurred for surgeons and paediatricians; these groups witnessed an increase of about 109 and $57 \%$ in their Gini coefficients, respectively, while the corresponding increase for anaesthetists and obstetricians was only about 20 and $27 \%$, respectively. In this regard, it must be noted that the Gini index for surgeons and paediatricians during 2002-2004 was smaller than that for obstetricians and anaesthetists (Figs. 1 and 2).

Table 5 Inter-CHC inequality for health professionals in Uttar Pradesh (India) between 2002-04 and 2012-13

\begin{tabular}{|c|c|c|c|c|c|c|}
\hline \multirow{2}{*}{$\begin{array}{l}\text { Health worker } \\
\text { category }\end{array}$} & \multirow{2}{*}{$\begin{array}{l}\text { Inequality } \\
\text { measure }\end{array}$} & \multicolumn{3}{|l|}{ Inequality } & \multicolumn{2}{|c|}{ Change between 2002-04 and 2012-13 } \\
\hline & & $2002-04(n=257)$ & $2007-08(n=693)$ & $2012-13(n=920)$ & Absolute & in \% \\
\hline \multirow[t]{2}{*}{ All Health Workers } & Theil T & 0.25 & 0.20 & 0.12 & & \\
\hline & Gini & 0.38 & 0.34 & 0.27 & -0.117 & -30.5 \\
\hline \multirow[t]{2}{*}{ Doctors } & Theil T & 0.66 & 0.27 & 0.23 & & \\
\hline & Gini & 0.57 & 0.35 & 0.36 & -0.210 & -37.0 \\
\hline \multirow[t]{2}{*}{ Nurses } & Theil T & 0.61 & 0.42 & 0.29 & & \\
\hline & Gini & 0.58 & 0.47 & 0.39 & -0.189 & -32.8 \\
\hline \multirow[t]{2}{*}{ Specialist } & Theil T & 0.34 & 0.79 & 1.14 & & \\
\hline & Gini & 0.41 & 0.63 & 0.74 & 0.325 & 78.3 \\
\hline \multirow[t]{2}{*}{ Surgeon } & Theil T & 0.51 & 1.34 & 1.98 & & \\
\hline & Gini & 0.42 & 0.74 & 0.87 & 0.452 & 108.6 \\
\hline \multirow[t]{2}{*}{ Paediatrician } & Theil T & 0.70 & 1.54 & 1.70 & & \\
\hline & Gini & 0.52 & 0.79 & 0.82 & 0.298 & 56.9 \\
\hline \multirow[t]{2}{*}{ Obstetrician } & Theil T & 1.02 & 1.24 & 1.67 & & \\
\hline & Gini & 0.65 & 0.73 & 0.83 & 0.179 & 27.5 \\
\hline \multirow[t]{2}{*}{ Anaesthetist } & Theil T & 1.40 & 1.80 & 2.30 & & \\
\hline & Gini & 0.75 & 0.84 & 0.91 & 0.152 & 20.1 \\
\hline
\end{tabular}




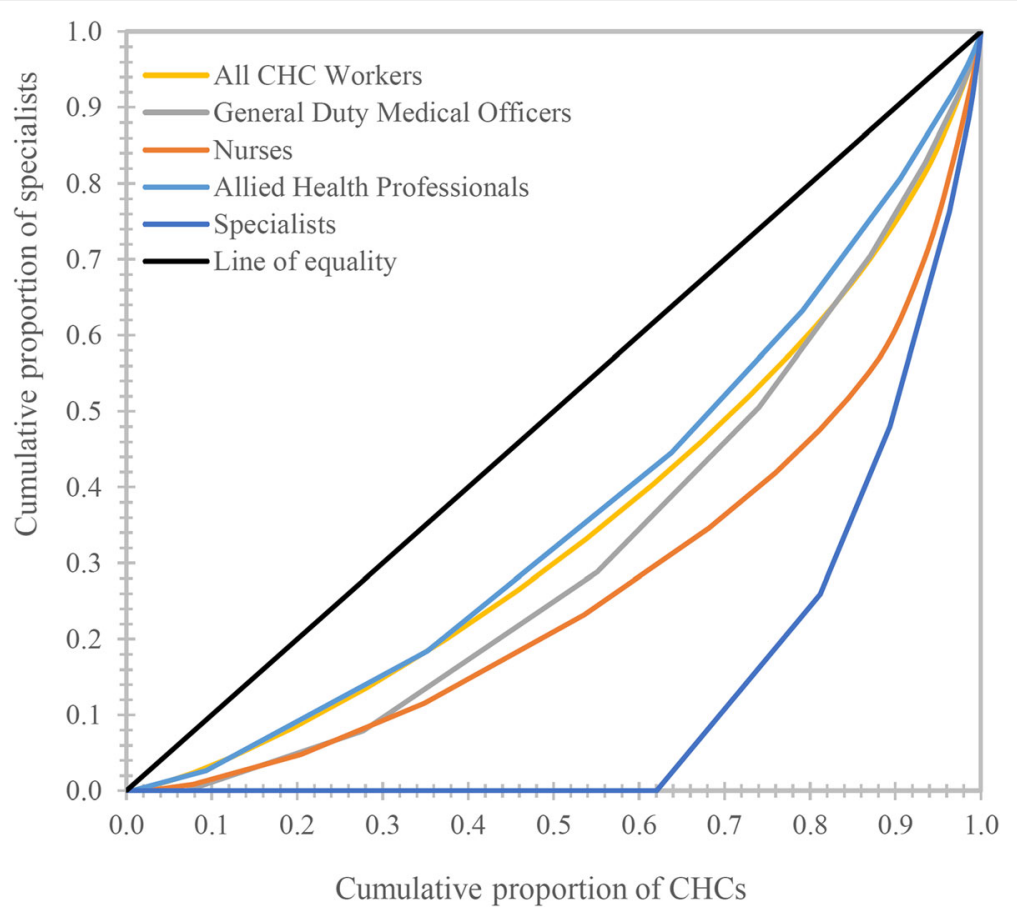

Fig. 1 Lorenz curve showing inequality in the distribution of health workers at CHCs in Uttar Pradesh, India, 2012-13 ( $n=920)$

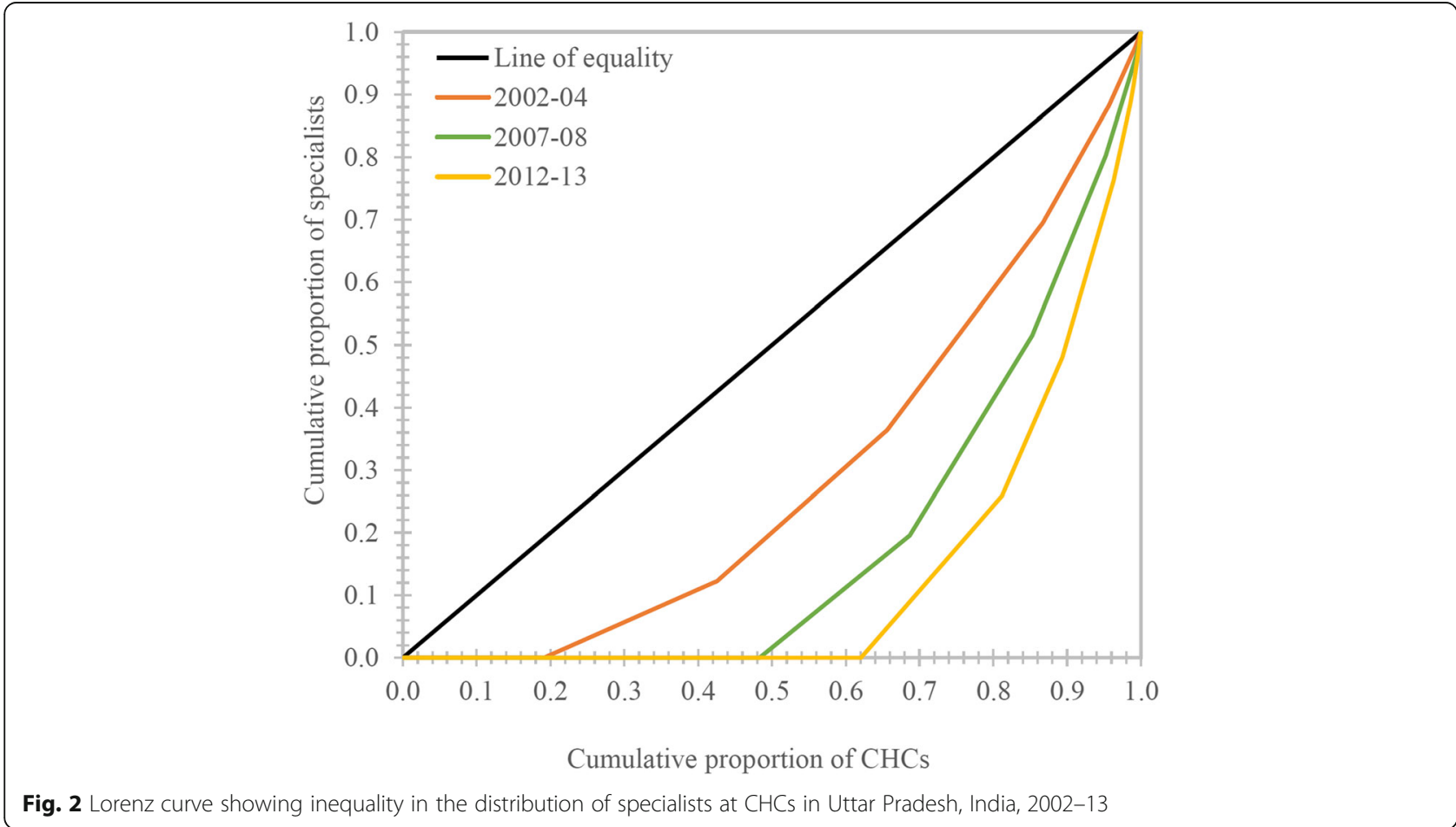

Fig. 2 Lorenz curve showing inequality in the distribution of specialists at CHCs in Uttar Pradesh, India, 2002-13 
Table 6 Decomposition of inter-CHC inequality by districts

\begin{tabular}{|c|c|c|c|c|c|c|}
\hline Period & $\begin{array}{l}\text { Inequality } \\
\text { measure }\end{array}$ & $\begin{array}{l}\text { Overall } \\
\text { inequality }\end{array}$ & $\begin{array}{l}\text { Within district } \\
\text { inequality }\end{array}$ & $\begin{array}{l}\text { Between district } \\
\text { inequality }\end{array}$ & $\begin{array}{l}\text { Within district inequality } \\
\text { (\% of overall) }\end{array}$ & $\begin{array}{l}\text { Between district inequality } \\
\text { (\% of overall) }\end{array}$ \\
\hline \multirow[t]{2}{*}{$2002-04(n=257)$} & Theil T & 0.34 & 0.26 & 0.09 & 74.0 & 26.0 \\
\hline & Gini & 0.41 & & & & \\
\hline \multirow[t]{2}{*}{$2007-08(n=693)$} & Theil T & 0.79 & 0.65 & 0.14 & 81.8 & 18.2 \\
\hline & Gini & 0.63 & & & & \\
\hline \multirow[t]{2}{*}{$2012-13(n=920)$} & Theil $\mathrm{T}$ & 1.14 & 0.98 & 0.17 & 85.4 & 14.6 \\
\hline & Gini & 0.74 & & & & \\
\hline
\end{tabular}

Thus, it is evident that the inequality in specialist distribution has risen over this period, while the same is not true for other categories of $\mathrm{CHC}$ health workers. The next section presents the results of the decomposition of overall inequality (Theil's 'T') on the current (2012-2013) distribution of specialists into within-district inequality and between-district inequality.

\section{Decomposition of overall inequality (Theil's ' $\mathrm{T}$ ')}

Table 6 provides the results of the decomposition of Theil's ' $\mathrm{T}$ ' for specialists into within- and between-district inequalities for all three time points. The between- and within-district values for 2012-2013 are 0.17 and 0.98, respectively, thus indicating that between- and within-district inequalities contribute about 18 and $82 \%$ to overall inequality, respectively. Although overall inequality has gone up considerably, the contribution of betweenand within-district inequalities to overall inequality has changed only slightly over time. The between-district inequalities witnessed a decline of about $8 \%$.

Figures 4 and 5 show the contribution of different districts to overall between- and within-district inequality. The contribution to between-district inequality is expressed in positive and negative values. Graph 4 reveals that the highest contribution to the overall between-district inequality comes from the districts of Lucknow, Kanpur Nagar, Chanduali, and Barabanki, while the highest negative contribution comes from the districts of Ballia and Pratapgarh. As for the contribution of different districts to the overall within-district inequality (Fig. 5), the highest contribution comes from the Badaun and Gorakhpur districts. Of the 70 districts in UP, the top 20 districts contribute about $52 \%$ of the total within-district inequality, and all except three belong to the Poorvanchal (Eastern UP) and Avadh region (Central UP). The lowest contribution to overall within-district inequality comes from the Chitrakoot and Lucknow districts. The districts falling on the left-hand side of the graph slightly contribution to the overall within-district inequality. Except for a few districts, most belong to Western UP. The state capital, Lucknow, is a curious case; its contribution to the overall between-district inequality is the highest among all districts in the state (an indication of higher per-CHC availability of specialists), while the contribution to within-district inequalities is the second lowest in the state. Figure 3 shows that there is a strong relationship between the average availability of specialists per $\mathrm{CHC}$ and the within-district inequality, as measured by Theil's ' $T$ '; Lucknow is an example of such a pattern (Figs. 3, 4 and 5).

\section{Factors associated with the distribution of specialists in CHCs Distribution of the characteristics of $\mathrm{CHCs}$}

Table 7 provides a glimpse into the facility characteristics, such as the number of workers available and the availability of residences, water, electricity, and some other variables (such as the location of a $\mathrm{CHC}$, its first referral unit (FRU) status, and the distance to district headquarters), that could influence the availability of specialists at the CHCs. A little over 50\% of CHCs in UP have fewer than ten health workers. A very small proportion of $\mathrm{CHCs}$ has $\geq 30$ health workers. About $21 \%$ of $\mathrm{CHCs}$ receive their water through a piped service, whereas about two-thirds of CHCs use bore wells, tube wells, or traditional wells for their water. About $2 \%$ do not have a water source within their premises at all. As for electricity, about $15 \%$ are running without a three-phase electricity connection. About one-fifth of all $\mathrm{CHCs}$ are designated as a FRU, and about $15 \%$ of $\mathrm{CHCs}$ are located in areas that are designated as 'urban' per the definition provided in the Census of India.

\section{Negative binomial regression results}

Table 7 presents the results of the negative binomial regression that has been performed to examine the association of facility characteristics with the number of specialists available in CHCs. Some factors have emerged as statistically significant during the analysis. The results indicate that the total number of health workers at a $\mathrm{CHC}$ is a significant predictor of specialist availability. The number of specialists at $\mathrm{CHCs}$ with fewer than ten workers is expected to decrease by about $43 \%$ with respect to the number of specialists at $\mathrm{CHCs}$ with more than 30 workers. Similarly, the number of residences 


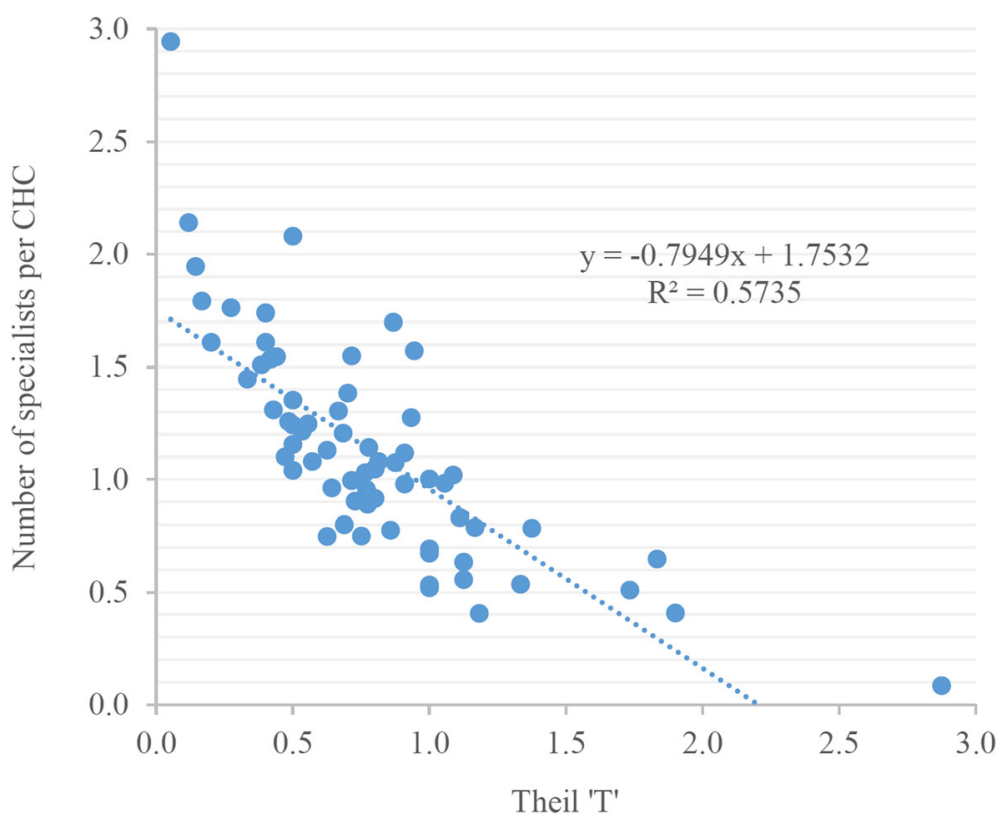

Fig. 3 The relationship between the average availability of specialists and the level of inequality in their distribution across 70 districts of Uttar Pradesh, 2012-13

available for specialists at a given $\mathrm{CHC}$ is also strongly associated with the number of specialists available at that location. The availability of specialists at the $\mathrm{CHCs}$ with one, two, and three residences is expected to be four, five, and six times higher, respectively than the $\mathrm{CHCs}$ without any residences. $\mathrm{CHCs}$ without a three-phase electricity connection are expected to have fewer specialists than those with a three-phase connection (IRR = 0.719). The rural location and non-FRU status of a $\mathrm{CHC}$ are also expected to reduce the number of specialists at a location. Non-FRUs are expected to have about $50 \%$ fewer specialists than FRUs (IRR $=0.518$ ). The distance from the $\mathrm{CHC}$ to district headquarters is also an important predictor of the availability of specialists at CHCs. Specifically, the further the $\mathrm{CHCs}$ is located from the district headquarters, the fewer specialists it is expected to have.

\section{Discussion}

The results indicate that the absolute number of specialists at CHCs in UP has increased from 2002 to 2013; however, the shortage of specialists in relation to the

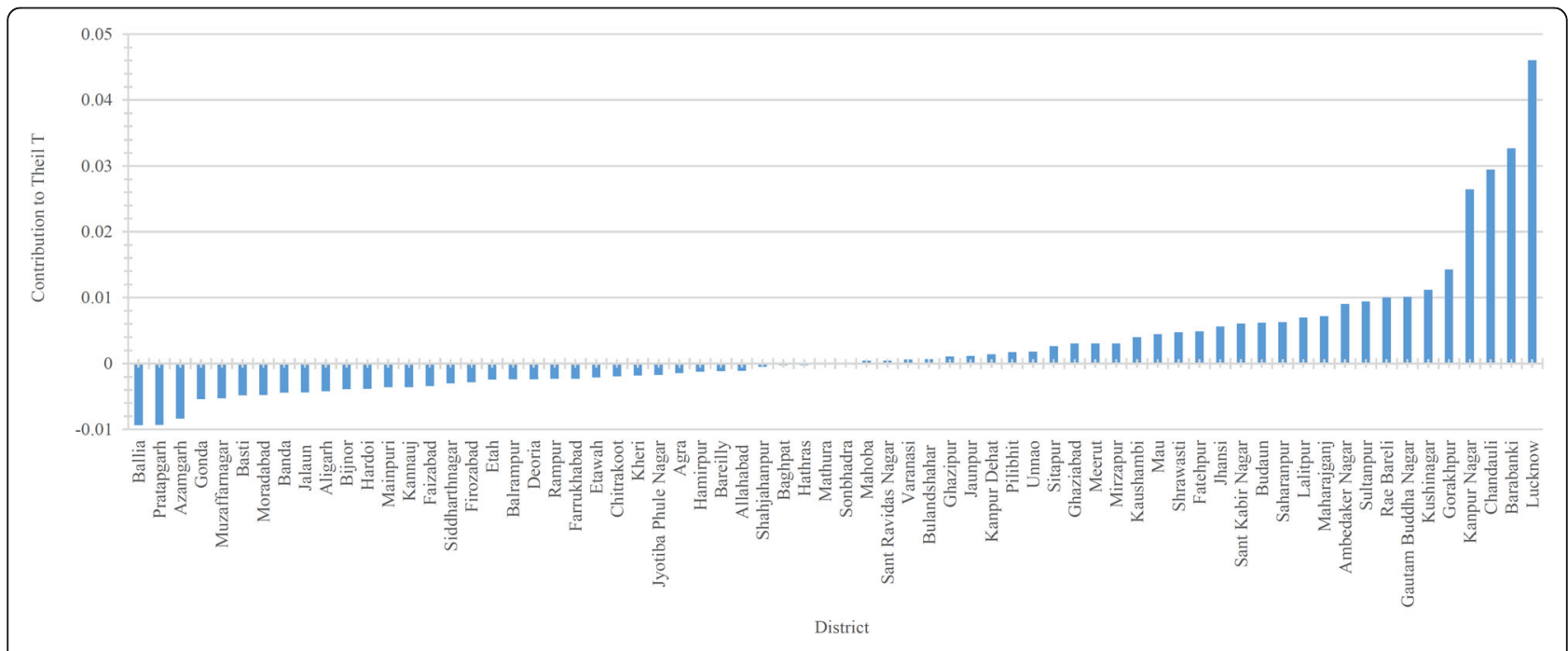

Fig. 4 Contribution of districts to the overall 'between-district' inequality, Uttar Pradesh, 2012-13 ( $n=920)$ 


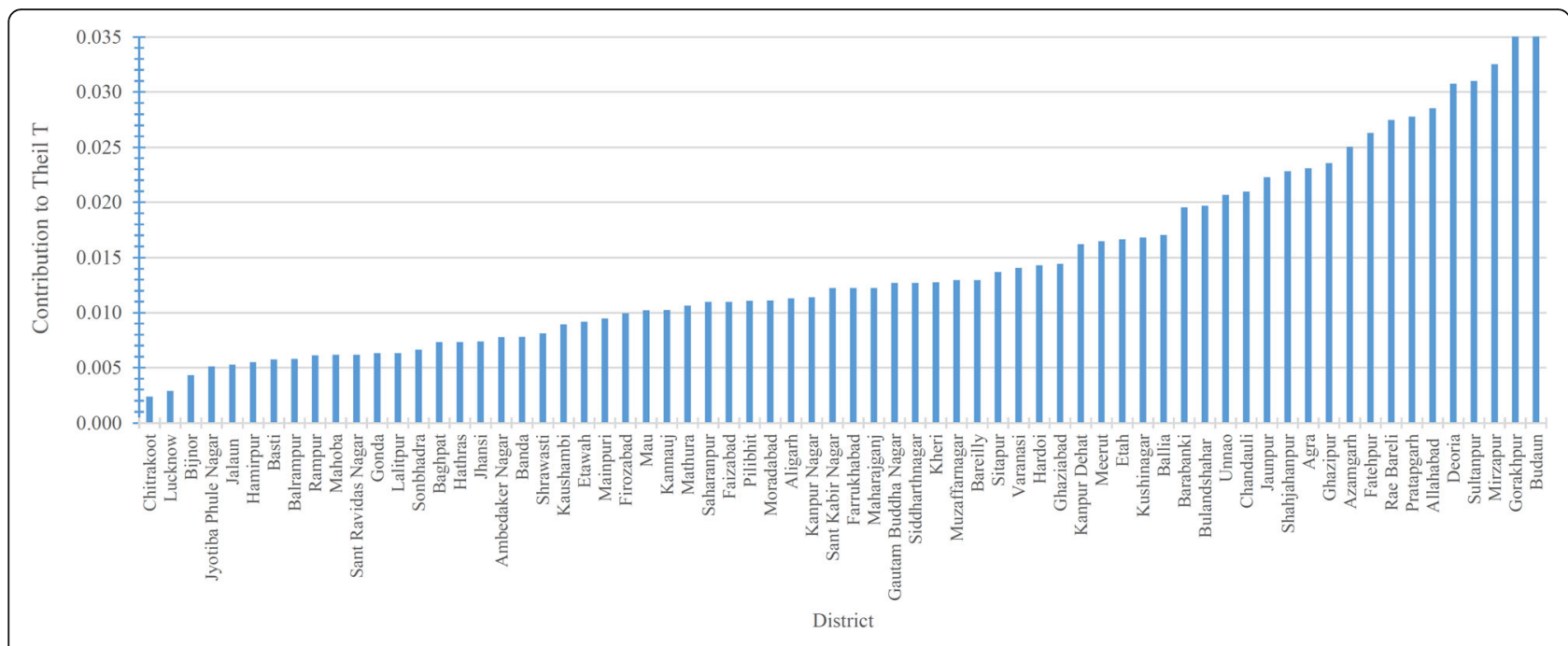

Fig. 5 Contribution of districts to the overall 'within-district' inequality, Uttar Pradesh, 2012-13 ( $n=920)$

Table 7 Results of negative binomial regression, 2012-13 $(n=920)$

\begin{tabular}{|c|c|c|c|c|c|c|c|}
\hline \multirow{2}{*}{$\begin{array}{l}\text { Independent } \\
\text { variables }\end{array}$} & \multirow[t]{2}{*}{ Categories } & \multirow{2}{*}{$\begin{array}{l}\text { Number } \\
\text { of } \mathrm{CHCs}\end{array}$} & \multirow[t]{2}{*}{$\%$} & \multicolumn{2}{|c|}{ Unadjusted } & \multicolumn{2}{|l|}{ Adjusted } \\
\hline & & & & $\mathrm{IRR}$ & $95 \% \mathrm{Cl}$ & IRR & $95 \% \mathrm{Cl}$ \\
\hline \multirow[t]{4}{*}{ Number of workers } & $30+{ }^{@}$ & 471 & 5.3 & & & & \\
\hline & $<10$ & 347 & 45.8 & $0.351^{* * *}$ & $0.225,0.548$ & $0.570^{* * *}$ & $0.403,0.806$ \\
\hline & $11--20$ & 53 & 41.2 & 0.752 & $0.484,1.168$ & 0.872 & $0.625,1.218$ \\
\hline & $20-30$ & 49 & 7.6 & $0.506^{* *}$ & $0.274,0.934$ & 0.629 & $0.385,1.029$ \\
\hline \multirow[t]{5}{*}{ Number of residences } & None ${ }^{@}$ & 493 & 53.6 & & & & \\
\hline & One & 125 & 13.6 & $4.634^{* * *}$ & $3.477,6.177$ & $3.864^{* * *}$ & $2.934,5.088$ \\
\hline & Two & 89 & 9.7 & $6.158^{* * *}$ & $4.531,8.37$ & $4.755^{* * *}$ & $3.543,6.383$ \\
\hline & Three & 78 & 8.5 & $8.574^{* * *}$ & $6.262,11.738$ & $6.206^{* * *}$ & $4.592,8.387$ \\
\hline & Four & 135 & 14.7 & $4.404^{* * *}$ & $3.293,5.891$ & $3.585^{* * *}$ & $2.703,4.754$ \\
\hline \multirow[t]{3}{*}{ Source of water } & Tap ${ }^{@}$ & 196 & 21.3 & & & & \\
\hline & Others & 707 & 76.9 & 0.787 & $0.603,1.026$ & 1.105 & $0.895,1.365$ \\
\hline & None & 17 & 1.9 & $0.272^{* *}$ & $0.084,0.879$ & 0.639 & $0.221,1.846$ \\
\hline \multirow[t]{2}{*}{ Electricity connection } & Yes $^{@}$ & 780 & 84.8 & & & & \\
\hline & No & 140 & 15.2 & $0.443^{* * *}$ & $0.307,0.639$ & $0.719^{*}$ & $0.516,1.001$ \\
\hline \multirow[t]{2}{*}{ FRU } & Yes $^{@}$ & 170 & 18.5 & & & & \\
\hline & No & 750 & 81.5 & $0.304^{* * *}$ & $0.242,0.382$ & $0.518^{* * *}$ & $0.428,0.627$ \\
\hline \multirow[t]{2}{*}{ Location } & Urban@ & 140 & 15.2 & & & & \\
\hline & Rural & 780 & 84.8 & $0.514^{* * *}$ & $0.389,0.68$ & $0.695^{* * *}$ & $0.560,0.863$ \\
\hline \multirow[t]{5}{*}{ Distance to DH } & $<=5 \mathrm{kms}^{@}$ & 26 & 2.8 & & & & \\
\hline & 6--10 kms & 37 & 4.0 & $0.366^{* *}$ & $0.146,0.917$ & $0.473^{*}$ & $0.224,1.002$ \\
\hline & $11--30 \mathrm{kms}$ & 451 & 49.0 & 0.748 & $0.397,1.409$ & $0.571^{* *}$ & $0.352,0.927$ \\
\hline & $31--50 \mathrm{kms}$ & 284 & 30.9 & 0.791 & $0.414,1.511$ & $0.574^{* *}$ & $0.350,0.941$ \\
\hline & $51+\mathrm{kms}$ & 122 & 13.3 & 0.739 & $0.371,1.471$ & 0.705 & $0.413,1.201$ \\
\hline
\end{tabular}

Alpha $=.4887607$

LR test of alpha $=0$ : chibar2(01) $=48.83$

Prob $>=$ chibar $2=0.000$

Note: IRR Incidence rate ratio, FRU First Referral Unit, DH District Headquarter, $C l$ Confidence Interval. @ = Reference Category, Level of significance: * indicates $p<0.10,{ }^{* *}$ indicates $p<0.05,{ }^{* * *}$ indicates $p<0.01$ 
requirement (as based on the number of $\mathrm{CHCs}$ ) has grown as well. This is due to the fact that the increase in the number of newly established $\mathrm{CHCs}$ has been far greater than the increase in the number of specialists recruited during the study period. The current shortage of specialists is about $80 \%$ of the total requirement (based on the current number of $\mathrm{CHCs}$ in the state). The overall shortage becomes significantly more acute if the population-based IPHS norms are applied to the current situation. The overall scenario indicates that the efforts being made to fill vacant positions for specialists at $\mathrm{CHCs}$ in the state are grossly insufficient.

There could be several reasons why the state government has not been able to increase the number of specialists in the system. First, there are simply not enough specialists graduating every year to fill the gap. For instance, the medical colleges in the state (including private ones) have only 93 and 74 postgraduate seats in total in obstetrics/gynaecology and paediatrics courses, respectively [42]. Even if one assumes that all obstetricians will join $\mathrm{CHCs}$ upon completion of their courses which, given the current policies, is obviously not going happen, it would still take six to 7 years to fill all vacant positions for obstetricians at the CHCs in UP. The same holds true for other categories of specialists as well.

One study found that the state has been 'lethargic' as far as recruitment of health workers is concerned [43]. It also argues that one of the reasons why the state is not able to recruit enough people could be the lack of candidates applying for the Provincial Medical Services, the method through which specialists in the state are recruited for their service in public health facilities [44]. It has been noted that a lot of those who do apply and get selected for these positions do not show up for the interview due to the lengthy recruitment process, leaving many posts vacant [45]. Since the state does not have a provision of waiting lists for regular appointments, there is no way to fill the posts left vacant by those who prefer not to join the services [43]. Many previous studies have found that specialist doctors are also recruited against the post of 'medical officer'. Such policy loopholes further aggravate the problem of specialist shortages in the system [44].

In the past, the state has tried to fill specialists positions through short-term contractual appointments, but this has been done with limited success [45]; in fact, only a few seats have been filled in the last 10 years [46]. A recent study has noted that district authorities who were in charge of implementing this measure were not very keen to take up such measures [4]. Although the state government has invited retired specialists to re-join the system this year to provide their services, the specialists' deployment is limited only to District Hospitals [47]; $\mathrm{CHCs}$ do not seem to be the priority at the moment.
Previous studies in other Indian states have found that most specialists, after they finish their studies, prefer private practice rather than joining public health system; this is done primarily for economic reasons [48]. Currently, the state of UP does not have strong financial and non-financial incentives for working in rural areas. Even those that do exist are too weak to offset the opportunity costs of working in the private sector [48-50]. Another obstacle associated with recruiting specialists is that the policy allows only those doctors who are registered in UP to join the system. Thus, specialists registered in other states cannot become a part of the state's public health system $[4,43]$. In addition, the huge shortage of a specialist workforce in the state is also the result of a lack of vision for the health workforce in rural public health facilities. It is surprising that the state still does not have a framework for medium- or long-term human resource for health (HRH) planning for its rural health system [51]. Moreover, the state also lacks a central HRH database that could help policymakers to keep an eye on HRH dynamics in the public health system [52].

Similar to previous small-scale studies, this study also found that a huge number of $\mathrm{CHCs}$ do not have the correct combination of specialists to provide emergency obstetric care or to conduct surgical interventions, such as caesarean section [51]. While some $\mathrm{CHCs}$ have a gynaecologist, but not an anaesthetist, there are other $\mathrm{CHCs}$ where the latter is posted without any surgeon. Also, there are many $\mathrm{CHCs}$ where an anaesthetist is posted alone without any paediatrician surgeon or obstetrician [4]. Such misallocation of the specialist workforce across $\mathrm{CHCs}$ can cause gross underutilization of the skills of specialist doctors, while also constituting a waste of financial resources [53]. Therefore, the government of UP should focus not only recruiting more specialists, but also on redistributing the existing specialist workforce in correct combinations to fully utilise their services.

The inequality analysis revealed that while the inequalities for doctors and nurses have decreased, the inequality in the distribution of specialists has increased during the study period (i.e., 2002-2013). The decomposition analysis indicated that the share of within-district inequality has always been higher than between-district inequality. It is interesting to note that the share of within-district inequality has risen steadily over the period. The current share of within-district inequality in terms of total inequality is about $85 \%$; therefore, the strategies to reduce inter- $\mathrm{CHC}$ inequality in the distribution of specialists should focus on those districts that contribute the most to overall within-district inequality. Several districts in the Poorvanchal (eastern UP) and Avadh (central UP) regions contribute heavily to the overall within-district inequalities. Most of these districts are characterised by low maternal and child healthcare 
utilisation when compared to the rest of the districts in the state [54]. They also lag behind in terms of socio-economic development [55]. Thus, the situation of these districts echoes what is known as Hart's 'law of inverse care', which states that the availability of good medical care tends to vary inversely with the need for it in the population served [56]. Therefore, the need of the hour is to update recruitment and deployment policies, so that they not only focus on improving the overall availability of specialists through increased recruitment activities in these districts, but also on equitable deployment of specialists within these districts.

The current distribution of specialists across $\mathrm{CHCs}$ could be the result of a number of factors ranging from recruitment and deployment policies of the state, to the personal choices made by doctors who, themselves, are affected by several factors such as working environment, amenities, availability of a residence, and travel times, and so on $[57,58]$. A recently conducted study revealed that most postings for doctors in the state are highly politicized and it is not unusual for doctors or health workers to use their political influence to cherry-pick their desired facility. The unavailability of doctors in many facilities across the state makes it even easier for them to get transferred to a place of their choice [44]. As a result, the facilities with the greatest need - largely those that are in far-off and poorly connected rural areas - are often neglected.

Utilizing the variables available in the latest dataset, this study also examined whether these variables are associated with specialist availability at the $\mathrm{CHCs}$ in the state. The results of the analysis revealed that the $\mathrm{CHCs}$ with a low number of health workers (fewer than 10) are expected to have a low number of specialists. It is possible that those $\mathrm{CHCs}$ with a low number of health workers face a higher burden of work that forces specialists to move out to health facilities staffed with higher numbers of health workers, thus experiencing relatively lower burden $[59,60]$. The results of the regression analysis also revealed that those $\mathrm{CHCs}$ that had residences available for specialists are expected to have a higher number of specialists than those $\mathrm{CHCs}$ that do not have residences for specialists. These results are in line with those of several previous studies conducted in developing countries [48, 61, 62]. For instance, several respondents from a study conducted in Malawi reported that poor housing conditions at the hospital served a factor that lead to demotivation; as such, these specialists left their jobs [63]. The same was found to be true for doctors from Ghana, who reported that they were willing to take rural posts, but the lack of work-based accommodations and delayed renovations forced them to give up a prospective rural post, and so they settled in a city instead [36]. It should be noted that over half of the CHCs in the state do not have residences for specialists.

Many previous studies showed how the availability of basic amenities, such as water and electricity, are regarded as necessary by health workers; similarly, the results of this study also showed that the lack of electricity connection is associated with a decrease in specialist availability. The supply of electricity in the state is highly regular and the rural areas receive electricity for only 6 $h$ a day, on average [64]. The urban life (electrical appliances are an integral part of daily life in urban areas) which specialist doctors are accustomed of and wish to lead, is nearly impossible in such rural settings. Given that a considerable number of $\mathrm{CHCs}$, especially the recently commissioned ones, in the state are often located in the outskirts of the main settlement, not having a regular supply of electricity poses a serious security threat, as a lack of lighting, especially during the night, makes them vulnerable to violence, theft, and burglary [50].

In this study, the location of a $\mathrm{CHC}$ has been found to be a significant predictor of the number of specialists available at a $\mathrm{CHC}$. It turns out that the $\mathrm{CHCs}$ located in rural areas of the state are likely to have fewer specialists than their urban counterparts, regardless of their FRU status. This finding is in tune with those of many previous studies, which have found that rural and remote health facilities are often poorly equipped and inadequately supplied with drugs [65], their physical working conditions are severe [49], the career growth opportunities are fewer [50], and staff are poorly supported or supervised and often feel isolated and neglected [66].

The unavailability of specialists in rural areas could be attributed to a number of push factors such as poor road connectivity, an unreliable public transport system, a lack of quality schooling for children, and so forth, that repel health workers from rural and remote areas [41, 57-59, $67,68]$. Most rural areas in the state have poor road connectivity and public transport is almost non-existent [69]. In such situations, the use of private vehicles becomes necessary. Since the state government does not provide any transportation or rural allowance [70] to travel to those $\mathrm{CHCs}$ located in rural and far-off areas, it is not difficult to understand why rural $\mathrm{CHCs}$ have fewer specialists when compared to their urban counterparts, which are well connected to district headquarters or major cities through major district roads and state highways. The unavailability of quality schooling for children in rural areas is another issue that is often quoted as a reason for not joining/leaving rural health services [67, 71]. The desire for specialist doctors to live with their families has also been noted as a reason for the lack of specialists in the rural public health system. In this regard, a recent study 


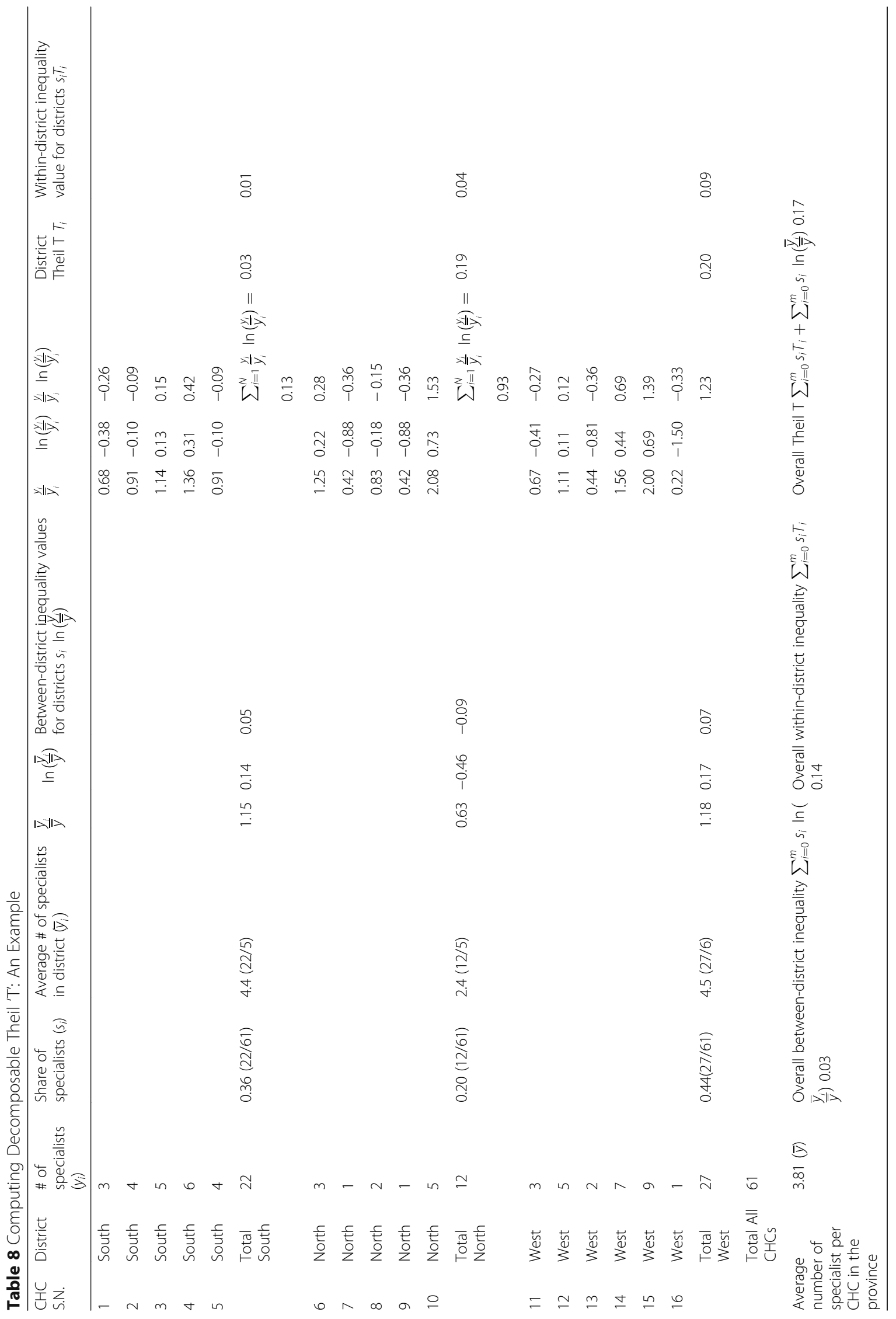


conducted in four North Indian states has found that a considerable proportion of specialists are willing to leave rural $\mathrm{CHCs}$ to live with their families in towns, cities, or district headquarters [4].

The study has several strengths. First, it contributes to the scant literature available on the issue of HRH shortage and the inequalities in the publicly funded health system in rural India. It is probably the first study to delve into the issues associated with specialist distribution in the public health system of UP. Unlike previous studies that featured small sample sizes, the present study included all rural hospitals of the state in question. Therefore, the reliability of the results is not an issue, and the findings can be used to inform policy development. Furthermore, the decomposable inequality measure applied in this study is a widely used and tested method in the field of HRH inequalities. The limitations of this study must be noted as well. First, given the cross-sectional nature of the dataset, casualty cannot be inferred. The relationship in the regression analysis may suffer from reverse casualty. It is possible that those $\mathrm{CHCs}$ where specialists are posted receive more resources and better facilities, or vice versa. Second, several factors such as personal preferences, working conditions and organizational environment, incentives, career growth opportunities, etc. that may affect the distribution of specialists across $\mathrm{CHCs}$ were not included in the analysis given the lack of such variables in the dataset. Third, the analysis does not address the situation after 2013. This is because the unit-level data on specialists for 2013 onwards is not available.

The present study has highlighted some critical issues related to the shortages and distributional inequalities of the specialist workforce in the Indian state of UP. Future research could undertake similar analysis for other Indian states; they can also analyse whether areas with higher numbers of specialists in the public health system are more likely to have better maternal and child health outcomes. Such an analysis could help policymakers decide upon the future roadmap to achieve maternal- and child-health-related sustainable development goals [26, 72].

\section{Conclusion}

The $\mathrm{CHCs}$ in the state are not only suffering from a huge shortage of specialists, but also from deep distributional inequalities in the existing workforce. The situation has become progressively worse over the study period. The shortage of specialists has shot up from 80 to $85 \%$ of the total requirement, and the inequality in their distribution has grown considerably as well. Decomposition analysis revealed that a large part of the overall inequality in the distribution of specialist doctors stems from within-district inequality. Moreover, the contribution of within-district inequality to overall inequality has steadily grown over time. The HRH policies in the state should thus focus not only on recruiting more specialists, but also on finding innovative strategies - such as rotation postings or higher monetary incentives for difficult and far-off areas - to influence the within-district distribution of specialists to make it more equitable. The focus should be on those districts from eastern UP where resources are highly concentrated in only a few CHCs. It has also been noted that rural $\mathrm{CHCs}$, on average, have fewer specialists when compared to their urban counterparts. Therefore, targeted attempts should be made to deploy and retain a specialist workforce in rural CHCs. Apart from recruiting and deploying more specialists, the government should ensure the availability of basic facilities such as water, electricity, and quality accommodations for doctors at the $\mathrm{CHCs}$, especially for those $\mathrm{CHCs}$ that are in interior locations and where commuting to the city is not possible. Future health workforce policies and interventions in the state should thus focus on increasing specialist availability in rural CHCs. From the discussion, it is clear that the state lacks strong monetary and non-monetary incentives/rewards for rural service that could stave off the negative effects of the rural location of the CHCs. This is a policy gap that the state government needs to consider immediately.

\section{Abbreviations}

CHC: Community Health Centre; DLHS: District Level Household Survey; FRU: First Referral Unit; HRH: Human Resource for Health; HSC: Health SubCentre; IMR: Infant Mortality Rate; IPHS: Indian Public Health Standards; IRR: Incidence Rate Ratios; MMR: Maternal Mortality Ratio; PHC: Primary Health Centre; UP: Uttar Pradesh; VIF: Variance Inflation Factor

\section{Acknowledgements}

None to report.

Funding

The author has no support or funding to report.

Availability of data and materials

The data used in this study is available for public use.

Authors' contributions

AS conceived and designed the study, analysed the data, and wrote the paper. The author read and approved the final manuscript.

Ethics approval and consent to participate

The study is based on dataset (with no identifiable information on the survey participants) that is available for public use.

\section{Consent for publication}

Yes.

Competing interests

The author declares that he has no competing interests.

\section{Publisher's Note}

Springer Nature remains neutral with regard to jurisdictional claims in published maps and institutional affiliations. 


\section{Received: 22 April 2019 Accepted: 29 April 2019}

\section{Published online: 24 May 2019}

\section{References}

1. Ministry of Health and Family Welfare. Indian public health standards: guidelines for community health Centres revised 2012 [internet]. New Delhi: Government of India; 2012. Available from: http://health.bih.nic.in/docs/ guidelines/guidelines-community-health-centres.pdf

2. Satpathy SK. Indian public health standards (IPHS) for community health centres. Indian J Public Health. 2005;49(3):123-6 [cited 2016 Mar 15]. Available from: http://www.ncbi.nlm.nih.gov/pubmed/16468274.

3. Rao PH. The private health sector in India : a framework for improving the quality of care. ASCI J Manag. 2012;41(2):14-39.

4. lyengar S, Dholakia RH. Specialist Services in the Indian Rural Public Health System for maternal and child healthcare - a study of four states. Ahmedabad: IIMA Working Paper Series; 2015. Report No.: 2015-07-04

5. Shahrawat R, Rao KD. Insured yet vulnerable: out-of-pocket payments and India's poor. Health Policy Plan. 2012;27(3):213-21 [cited 2017 Jun 7] Available from: https://academic.oup.com/heapol/article-lookup/doi/10. 1093/heapol/czr029.

6. Chandra R, Singh A, Mukherjee S. A disaggregated analysis of change in household out-of-pocket expenditure on healthcare in India out of pocket expenditure on health care. Int J Public Heal Res. 2013;3(1):257-66.

7. Garg CC, Karan AK. Reducing out-of-pocket expenditures to reduce poverty: a disaggregated analysis at rural-urban and state level in India. Health Policy Plan. 2009;24(2):116-28 [cited 2017 Jun 7] Available from: https://academic. oup.com/heapol/article-lookup/doi/10.1093/heapol/czn046.

8. Singh MM. Operationalizing an effective referral system in India. BMJ. 2015; 315:h5489 Available from: http://www.bmj.com/content/351/bmj.h5489/rr.

9. Zurn P, Dal Poz MR, Stilwell B, Adams O, Poz MRD, Stilwell B, et al. Imbalance in the health workforce. Hum Resour Health. 2004;2(13):1-12 [cited 2012 Mar 5] Available from: http://www.pubmedcentral.nih.gov/ articlerender.fcgi?artid=526216\&tool=pmcentrez\&rendertype=abstract.

10. Government of India. Ministry of Home Affairs. Size, growth rate and distribution of population [internet]. In: Census of India. New Delhi: Office of the Registrar General \& Census Commissioner, India; 2011. Available from: http://censusindia.gov.in/2011-prov-results/data_files/india/Final_PPT_2011_ chapter3.pdf.

11. Munshi V, Yamey G, Verguet S. Trends in state-level child mortality, maternal mortality, and fertility rates in India. Health Aff. 2016;35(10):1759-63.

12. Ministry of Health and Family Welfare. Rural Health Statistics 2014-15. New Delhi: Government of India; 2014.

13. Anand S. Measuring health workforce inequalities: methods and application to China and India [internet], vol. 5. Geneva: Human Resources for Health Observer; 2010. [cited 2012 Mar 1]. Report No.: 5. Available from: http:// www.who.int/hrh/resources/observer/en/

14. Hazarika I. Health workforce in India: assessment of availability, production and distribution. WHO South-East Asia J Public Heal. 2013;2(2):106 [cited 2016 Feb 20] Available from: http://www.who-seajph.org/article.asp?issn=2224-3151; year $=2013$; volume $=2 ;$ issue $=2 ;$ spage $=106 ;$ epage $=112$; aulast $=$ Hazarika .

15. Pallikadavath S, Singh A, Ogollah R, Dean T, Stones W. Human resource inequalities at the base of India's public health care system. Health Place. 2013;23:26-32 [cited 2016 Mar 4] Available from: http://www.sciencedirect. com/science/article/pii/S1353829213000725.

16. Rao KD, Bhatnagar A, Berman P. So many, yet few: human resources for health in India. Hum Resour Health. 2012;10(1):19 Available from: http://humanresources-health.biomedcentral.com/articles/10.1186/1478-4491-10-19.

17. Rao M, Rao KD, Kumar AKS, Chatterjee M, Sundararaman T. Human resources for health in India. Lancet. 2011;377(9765):587-98 [cited 2012 Mar 5] Available from: http://www.thelancet.com/article/S0140673610618880/fulltext.

18. Kiadaliri AA, Hosseinpour R, Haghparast-Bidgoli H, Gerdtham U-G. Pure and social disparities in distribution of dentists: a cross-sectional province-based study in Iran. Int J Environ Res Public Health. 2013;10(5):1882-94 [cited 2016 Mar 9] Available from: http://www.pubmedcentral.nih.gov/articlerender. fcgi?artid=3709354\&tool=pmcentrez\&rendertype=abstract.

19. Ohba H, Narumi M, Hosokawa Y, Aoki M. Measuring the inequalities in radiotherapy health resources in Japan: comparison of the HokkaidoTohoku and Tokyo districts. Jpn J Radiol. 2010;28(1):20-6 [cited 2016 Mar 9] Available from: http://www.ncbi.nlm.nih.gov/pubmed/20112089.

20. Tanikawa T, Ohba H, Ogasawara K, Okuda Y, Ando Y. Geographical distribution of radiotherapy resources in Japan: investigating the inequitable distribution of human resources by using the Gini coefficient. J Radiat Res 2012;53(3):489-91 [cited 2016 Mar 9] Available from: http://www.ncbi.nlm. nih.gov/pubmed/22739017.

21. Dhingra B, Dutta AK. National Rural Health Mission. Indian J Pediatr. 2011. 78(12):1520-6 [cited 2016 May 10] Available from: http://www.ncbi.nlm.nih. gov/pubmed/21830029.

22. Lambert PJ, Aronson JR. Inequality decomposition analysis and the Gini coefficient revisited. Econ J. 1993;103(420):1221-7.

23. Bartley M. Health inequality: an introduction to theories, Concepts and Methods. Cambridge: Polity Press; 2004.

24. Anand S, Fan VY, Zhang J, Zhang L, Ke Y, Dong Z, et al. China's human resources for health: quantity, quality, and distribution. Lancet (London, England). 2008;372(9651):1774-81 [cited 2016 Mar 9] Available from: http:// www.thelancet.com/article/S014067360861363X/fulltext.

25. Goesling B, Firebaugh $\mathrm{G}$. The trend in international health inequality. Popul Dev Rev. 2004;30(1):131-46 [cited 2016 Apr 14] Available from: http://doi. wiley.com/10.1111/j.1728-4457.2004.00006.x.

26. Sousa A, Dal Poz MR, Carvalho CL. Monitoring inequalities in the health workforce: the case study of Brazil 1991-2005. PLoS One. 2012;7(3):e33399 [cited 2016 Mar 10] Available from: http://journals.plos.org/plosone/ article?id=10.1371/journal.pone.0033399.

27. Speybroeck N, Paraje G, Prasad A, Goovaerts P, Ebener S, Evans DB. Inequality in human resources for health: measurement issues. Geogr Anal. 2012;44(2):151-61 [cited 2016 Apr 8] Available from: https://www.ncbi.nlm. nih.gov/pmc/articles/PMC3378331/.

28. Bellù LG, Liberati P. Inequality Analysis: The Gini Index. Geneva: Food and agriculture Organization of the United Nations; 2006. p. 1-25. Available from: http://www.fao.org/docs/up/easypol/329/gini_index_040en.pdf

29. Jenkins S. INEQDECO: Stata module to calculate inequality indices with decomposition by subgroup [internet], Statistical Software Components: Boston College Department of Economics; 2015. [cited 2016 Sep 16]. Available from: https://ideas.repec.org/c/boc/bocode/s366002.html

30. Coxe S, West SG, Aiken LS. The analysis of count data: a gentle introduction to Poisson regression and its alternatives. J Pers Assess. 2009;91(2):121-36 [cited 2016 Apr 9] Available from: http://www.tandfonline.com/doi/full/10. 1080/00223890802634175.

31. Land KC, PL MC, Nagin DS. A Comparison of Poisson, Negative Binomial, and Semiparametric Mixed Poisson Regression Models: With Empirical Applications to Criminal Careers Data. Sociol Methods Res. 1996;24(4):387-442 [cited 2016 Apr 9] Available from: http://smr.sagepub.com/content/24/4/387.

32. Gardner W, Mulvey EP, Shaw EC. Regression analyses of counts and rates: Poisson, overdispersed Poisson, and negative binomial models. Psychol Bull. 1995;118(3):392-404 [cited 2016 Apr 9] Available from: http://www.ncbi.nIm. nih.gov/pubmed/7501743.

33. StataCorp. Stata statistical software: release 12. College Station: StataCorp LP 2011. Available from: http://www.stata.com/support/faqs/resources/citingsoftware-documentation-faqs/

34. Awofeso N. Improving health workforce recruitment and retention in rural and remote regions of Nigeria. Rural Remote Health. 2010;10(1):1319 Jan [cited 2016 Mar 4] Available from: http://www.ncbi.n/m.nih.gov/pubmed/ 20136347.

35. Mathauer I, Imhoff I. Health worker motivation in Africa: the role of nonfinancial incentives and human resource management tools. Hum Resour Health. 2006:4:24 Jan [cited 2016 Mar 14] Available from: http://www. pubmedcentral.nih.gov/articlerender.fcgi?artid=1592506\&tool= pmcentrez\&rendertype $=$ abstract.

36. Snow RC, Asabir K, Mutumba M, Koomson E, Gyan K, Dzodzomenyo M, et al. Key factors leading to reduced recruitment and retention of health professionals in remote areas of Ghana: a qualitative study and proposed policy solutions. Hum Resour Health. 2011;9:13 [cited 2016 Mar 14] Available from: http://www.pubmedcentral.nih.gov/articlerender.fcgi?artid= 3127976\&tool=pmcentrez\&rendertype=abstract.

37. Kotzee TJ, Couper ID. What interventions do South African qualified doctors think will retain them in rural hospitals of the Limpopo province of South Africa? Rural Remote Health. 2006;6(3):581 [cited 2016 Mar 14] Available from: http://www.ncbi.n/m.nih.gov/pubmed/16965219.

38. Wurie HR, Samai M, Witter S. Retention of health workers in rural Sierra Leone: findings from life histories. Hum Resour Health. 2016; 14(1):3 [cited 2016 Mar 29] Available from: http://www.pubmedcentral. nih.gov/articlerender.fcgi?artid=4736088\&tool=pmcentrez\&rendertype $=$ abstract. 
39. Wilson NW, Couper ID, De Vries E, Reid S, Fish T, Marais BJ. A critical review of interventions to redress the inequitable distribution of healthcare professionals to rural and remote areas. Rural Remote Health. 2009;9(2):1060 [cited 2016 Mar 4] Available from: http://www.ncbi.nlm.nih.gov/pubmed/ 19530891.

40. de Vries E, Reid S. Do south African medical students of rural origin return to rural practice? S Afr Med J. 2003;93(10):789-93 [cited 2016 Feb 11] Available from: http://www.ncbi.nlm.nih.gov/pubmed/14652974.

41. Lisam S, Nandi S, Kanungo K, Verma P, Mishra JP, Mairembam DS. Strategies for attraction and retention of health workers in remote and difficult-toaccess areas of Chhattisgarh, India: do they work? Indian J Public Health. 2015;59(3):189-95 [cited 2016 Mar 4] Available from: http://www.ncbi.nlm. nih.gov/pubmed/26354394.

42. Medical Council of India. List of colleges teaching PG courses [internet]. 2016 [cited 2016 Apr 29]. Available from: https://www.mciindia.org/CMS/ information-desk/college-and-course-search.

43. Ministry of Health and Family Welfare. 6th Common Review Mission report: Uttar Pradesh. New Delhi: Government of India; 2012.

44. Bajpai N, Dholakia R, Vynatheya J. Increasing the availability of skilled birth in rural India. New York: CGC | SA Working Paper Series; 2013. Report No.: 8

45. Raha $S$, Bermen $P$, Rao KD. Challenges in recruitment of doctors by government. Indian Heal Beat. 2009;1(4):1-4.

46. International Institute for Population Sciences (IIPS). District Level Household and Facility Survey (DLHS-3), 2007-08. Mumbi: IIPS.

47. UP Medical and Health Services. Order for reappointment and extension of retired specilist medical officers, 157/sec-2-5-14-7(255)/13 Uttar Pradesh, India: Director General, Medical and Health Services, Uttar Pradesh; 2016. p. 1-3.

48. Ramani S, Rao KD, Ryan M, Vujicic M, Berman P. For more than love or money: attitudes of student and in-service health workers towards rural service in India. Hum Resour Health. 2013;11:58 [cited 2016 Mar 14] Available from: http://www.pubmedcentral.nih.gov/articlerender.fcgi?artid= 4222605\&tool=pmcentrez\&rendertype=abstract.

49. Bajpai V. The challenges confronting public hospitals in India, their origins, and possible solutions. Adv Public Heal. 2014;2014:1-27 Available from: http://www.hindawi.com/journals/aph/2014/898502/.

50. Rao KD, Ramani S, Murthy S, Hazarika I, Khandpur N, Chokshi M, et al. Health worker attitudes toward rural service in India: results from qualitative research. Washington DC: The International Bank for Reconstruction and Development / The World Bank 2010.

51. MOHFW (GOI). 7th Common Review Mission report: Uttar Pradesh. New Delhi: Government of India; 2013. Available from: http://www.nhm.gov.in/ images/pdf/monitoring/crm/7th-crm/report/7th_CRM_Report_UP.pdf.

52. Nandan D, Nair KS. Human resources for public health in India - issues and. Heal Popul Issues. 2007;30(4):230-42 Available from: http://medind.nic.in/ hab/t07/i4/habt07i4p230.pdf

53. Sundararaman T, Gupta G. Human resource for health : the crisis, the NRHM response and the policy options. New Delhi: National Health System Resource Centre, Government of India; 2006. Available from: http:// nhsrcindia.org/sites/default/files/ HRH\%20Crisis\%20NRHM\%20Response\%20and\%20Policy\%20.

54. Office of Registrar General of India. Annual Health Survey Bulletin 2010-11: Uttar Pradesh [internet]. New Delhi: Government of India; 2013. Available from: http://censusindia.gov.in/vital_statistics/AHSBulletins/files/01Uttar\%20Pradesh\%20AHS\%20Bulletin.pdf

55. Government of Uttar Pradesh. Human Development Report, Uttar Pradesh. Lucknow: Planning Department, Govt. of Uttar Pradesh; 2007.

56. Hart JT. The inverse care law. Lancet (London, England). 1971;1(7696): 405-12 [cited 2016 Feb 16] Available from: http://www.ncbi.nlm.nih. gov/pubmed/4100731

57. World Health Organization. Increasing access to health worker in remote and rural areas through improved retention. Geneva: World Health Organization; 2010.

58. Kadam S, Nallala S, Zodpey S, Pati S, Hussain MA, Chauhan AS, et al. A study of organizational versus individual needs related to recruitment, deployment and promotion of doctors working in the government health system in Odisha state, India. Hum Resour Health. 2016;14(1):7 [cited 2016 Mar 29] Available from: http://www.ncbi.nlm.nih.gov/ pubmed/26911674

59. Willis-Shattuck M, Bidwell P, Thomas S, Wyness L, Blaauw D, Ditlopo P. Motivation and retention of health workers in developing countries: a systematic review. BMC Health Serv Res. 2008;8(1):247 [cited 2012 Mar 5]
Available from: http://bmchealthservres.biomedcentral.com/articles/10.1186/ 1472-6963-8-247.

60. Bhattacharya I, Ramachandran A. A path analysis study of retention of healthcare professionals in urban India using health information technology. Hum Resour Health. 2015;13(1):65 Available from: http://human-resourceshealth.biomedcentral.com/articles/10.1186/s12960-015-0055-x.

61. Kruk ME, Prescott MR, de Pinho H, Galea S. Are doctors and nurses associated with coverage of essential health services in developing countries? A cross-sectional study. Hum Resour Health. 2009;7(1):27 [cited 2016 Mar 14] Available from: http://human-resources-health.biomedcentral. com/articles/10.1186/1478-4491-7-27.

62. Ramani S, Rao KD, Ryan M, Vujicic M, Berman P, Mullei K, et al. Attracting and retaining health workers in rural areas: investigating nurses' views on rural posts and policy interventions. BMC Health Serv Res. 2010;10(Suppl 1): S1 [cited 2016 Mar 14] Available from: http://bmchealthservres. biomedcentral.com/articles/10.1186/1472-6963-10-S1-S1.

63. Chimwaza W, Chipeta E, Ngwira A, Kamwendo F, Taulo F, Bradley S, et al. What makes staff consider leaving the health service in Malawi? Hum Resour Health. 2014;12:17 [cited 2016 Mar 14] Available from: http://www. pubmedcentral.nih.gov/articlerender.fcgi?artid=3974437\&tool= pmcentrez\&rendertype=abstract.

64. Modi V. Improving electricity services in rural India. New York: Center on Globalization and Sustainable Development Working Paper Series; 2005. Report No.: 30

65. Prinja S, Bahuguna P, Tripathy JP, Kumar R. Availability of medicines in public sector health facilities of two north Indian states. BMC Pharmaco Toxicol. 2015;16(1):43 Available from: http://www.pubmedcentral.nih.gov/ articlerender.fcgi?artid $=4690305 \&$ tool=pmcentrez\&rendertype $=$ abstract.

66. Chhea C, Warren N, Manderson L. Health worker effectiveness and retention in rural Cambodia. Rural Remote Health. 2010;10(3):1391 [cited 2016 Mar 14] Available from: http://www.ncbi.nlm.nih.gov/pubmed/20701412.

67. Kadam S, Pati S, Hussain MA, Nallala S, Chakravarty N, Panda B, et al. Assessment of factors influencing retention of health workforce in rural and remote areas of Odisha, India. BMC Proc. 2012;6(Suppl 5):O4 [cited 2016 Mar 14] Available from: http://bmcproc.biomedcentral.com/articles/10.1186/ 1753-6561-6-S5-04.

68. Lehmann U, Dieleman M, Martineau T. Staffing remote rural areas in middle- and low-income countries: a literature review of attraction and retention. BMC Health Serv Res. 2008;8:19 [cited 2016 Mar 4] Available from: http://www.pubmedcentral.nih.gov/articlerender.fcgi?artid=2259330\&tool= pmcentrez\&rendertype=abstract.

69. Sinha D. Women, health and public services in India: why are states different? New Delhi: Routledge; 2016. p. 1-244.

70. Chaudhuri A, Kumar S, Joseph J, Bhowmik A, Veenam S, Sharma I. Motivation, compensation and retention of health workforce. New Delhi: Swasti; 2013. Available from: http://swasti.org/wp-content/uploads/2018/03/MotivationCompensation-Retention-of-Health-Workforce.pdf

71. Ageyi-Baffour P, Rominski S, Nakua E, Gyakobo M, Lori JR. Factors that influence midwifery students in Ghana when deciding where to practice: a discrete choice experiment. BMC Med Educ. 2013;13:64 [cited 2016 Mar 14] Available from: http://www.pubmedcentral.nih.gov/articlerender.fcgi?artid= 3684532\&tool=pmcentrez\&rendertype=abstract.

72. Buse K, Hawkes S. Health in the sustainable development goals: ready for a paradigm shift? Global Health. 2015;11(1):13 Available from: http://www. globalizationandhealth.com/content/11/1/13.

\section{Ready to submit your research? Choose BMC and benefit from:}

- fast, convenient online submission

- thorough peer review by experienced researchers in your field

- rapid publication on acceptance

- support for research data, including large and complex data types

- gold Open Access which fosters wider collaboration and increased citations

- maximum visibility for your research: over $100 \mathrm{M}$ website views per year

At $\mathrm{BMC}$, research is always in progress.

Learn more biomedcentral.com/submission 